\title{
The termites of Barrow Island, Western Australia
}

\author{
David T. Jones \\ Soil Biodiversity Group, Natural History Museum, London, SW7 5BD, United Kingdom. \\ Email: david.jones@nhm.ac.uk
}

\begin{abstract}
Forty years ago D. H. Perry, the renowned termite expert, published a checklist of 18 species that he had collected on Barrow Island. That checklist is now updated with the results of a recent invertebrate survey of the island, and a literature search for additional records. The updated list now runs to 27 species, all of which appear to be indigenous to the island.
\end{abstract}

KEYWORDS: Isoptera, Nasutitermitinae, Rhinotermitidae, Termitinae.

\section{INTRODUCTION}

Barrow Island $\left(20.79^{\circ} \mathrm{S}, 115.41^{\circ} \mathrm{E}\right)$ lies $50 \mathrm{~km}$ off the coast of Western Australia and is approximately $230 \mathrm{~km}^{2}$ in size. The natural history of the island has been summarised by Callan et al. (2011). It has a semi-arid tropical climate, and the vegetation is dominated by spinifex (Triodia spp.) hummocks and sparse Acacia shrubs. Barrow Island represents a near-intact Australian ecosystem as, unlike the mainland, it has not been greatly affected by agriculture or introduced species.

Oil was discovered on Barrow Island in the 1960s, and today the island has Australia's largest onshore oilfield, with oil and natural gas wells across much of the southern half of the island. Offshore to the north-west lie the Greater Gorgon natural gas fields, and the island is now being developed as the infrastructure hub for the Gorgon gas project. At the centre of the project is a liquefied natural gas (LNG) facility which is currently under construction on the eastern coast of the island.

An intensive baseline survey of terrestrial invertebrates was undertaken on the island between 2005 and 2009, as part of the LNG facility environmental impact assessment. The aim of the survey was to make a representative assessment of the fauna, to understand the determinants of the composition of the invertebrate assemblages, to investigate the impact of human activity on these assemblages, and to determine if any nonindigenous species were already on the island. Details of the survey and preliminary findings are presented by Callan et al. (2011).

Termites are often highly conspicuous in Australian ecosystems because of their mounds
(Abensperg-Traun and Perry 1998). These eusocial insects have a major role in decomposition, nutrient recycling and soil translocation (Lee and Wood 1971; Holt and Lepage 2000). Prior to the current survey, the only published study focussing explicitly on the termites of Barrow Island was Perry's (1972) work which included a checklist of 15 taxa identified to named species, and a further ten taxa identified to genus and referred to as $s p$. nov. The aim of this paper is to use the results of the current survey to compile an up-to-date checklist of the termites of Barrow Island, and to assess whether any may be non-indigenous. Additional records were also sought in the literature.

\section{METHODS}

During the 2005-2009 baseline survey terrestrial invertebrates were collected from 57 sites across the island. Four methods of collecting were undertaken: (1) pitfall trapping, (2) beat sampling and vacuum sampling of trees, shrubs and groundlevel vegetation including herbs and grasses, (3) leaf-litter sampling involving collecting by hand, and sieving coarse litter followed by Winkler bag extraction, and (4) nocturnal and diurnal hand searching to target cryptic and complex microhabitats such as burrows, termite mounds, and under woody debris and rock piles. Samples were processed, sorted to taxonomic order, and then sent to specialists for identification. Full details of the collecting methods, descriptions of sampling sites, and details of processing methods are given in Callan et al. (2011).

Termite specimens were sent to the Natural History Museum (London) for identification. 
Soldiers were identified using published species descriptions (notably Hill 1942, Gay 1968, Watson and Perry 1981) and the extensive collection of Australian termites in the NHM collection. Alates and workers were difficult to identify because in most cases species descriptions do not exist.

Apart from those species listed by Perry (1972), additional records were sought by checking all the species accounts in the Atlas of Australian Termites (Watson and Abbey 1993) and the Zoological Catalogue of Australia (Watson, Miller and Abbey 1998) for specific references to Barrow Island. The online ISI Web of Knowledge was searched using "Barrow Island", "termites" and "Isoptera" as keywords.

\section{RESULTS}

Perry's (1972) species list is given in Table 1. His three Drepanotermes sp. nov. were subsequently described as D. basidens, $D$. dibolia and $D$. diversicolor by Watson and Perry (1981). Part of Perry's Barrow Island collection was eventually deposited at the Western Australian Museum (WAM). Details of this material were provided by WAM (Table 1), and list an additional five species, taking Perry's collection to 23 named species. The Atlas of Australian Termites and the Zoological Catalogue of Australia list 14 and 11 species respectively as occurring on Barrow Island (Table 1), including Amitermes subtilis which was not on Perry's list. No other references to named species on Barrow Island could be found in the literature.

The 2005-2009 survey produced 103 series of termites from 24 different sites on Barrow Island. Of these, some contained more than one species, and 41 series contained only workers or alates that could not be identified to species. All series contained limited numbers of specimens. A total of 13 species were determined (Table 1), of which Schedorhinotermes cf. reticulatus and Tumulitermes cf. peracutus are uncertain because only a single soldier was collected in each case. Four taxa are new to Perry's list: Nasutitermes eucalypti, N. magnus, Tumulitermes hastilis and T. cf. peracutus.

\section{DISCUSSION}

Having compiled all available records, the termite checklist for Barrow Island now stands at 27 named species. The uncertain taxa in Table 1 (Tumulitrermes cf. peracutus and Perry's seven remaining new species) are excluded from that total. Ten named species on Perry's list are not recorded as present on Barrow Island in the Atlas of Australian Termites and the Zoological Catalogue of Australia. Perry (1972) stated that one or more series of each species would be deposited with the Australian National Insect Collection (ANIC). However, the Atlas was compiled using published records and identified material in the ANIC, so these discrepancies remain a mystery. The fact that the Atlas records Amitermes subtilis on Barrow Island while this species was not on Perry's original list suggests subsequent reclassification of Perry's specimens, or that additional collections from Barrow Island exist in the ANIC.

Despite the intensive sampling carried out during the 2005-2009 survey, only eleven named species of termite were collected. This is mainly because most of the sampling methods used (pitfall trapping, beating and vacuuming of vegetation, and leaf litter sampling) are not efficient at collecting termites. In contrast, the final sampling method, which included hand searching of termite mounds and woody debris, could have been expected to be more fruitful. Given the size of the island, the sampling to date has not been exhaustive, and future sampling targeted at known termite microhabitats using appropriate methods will undoubtedly turn up additional species.

Perry (1972) mentions that three species (without explaining which), all wood-feeders, were found in mangrove logs lying above high water in the coastal mangrove thickets. Information from Perry's collection supplied by WAM reveals two of these to be Schedorhinotermes reticulatus and Microcerotermes distinctus. Unfortunately, the information available for the rest of Perry's collection, and the very limited number of series from the 2005-2009 survey, means it is not possible to assign habitat associations to any of the species.

All but two of the species in the present Barrow Island list (Table 1) also occur in adjacent areas of Western Australia. Nasutitermes magnus is mainly found in Queensland, with some records in New South Wales and Northern Territories (Watson and Abbey 1993). However, it has also been recorded from the Montebello Islands, $20 \mathrm{~km}$ north of Barrow Island (Watson et al. 1998). The other exception is Amitermes subtilis which is widely distributed across much of northern Australia but infrequent in Western Australia (Watson and Abbey 1993). These two species are unlikely candidates for accidental introductions, as the first feeds on grass and the second on woody debris. In contrast, all introduced or non-indigenous termite species have been transported in the sound heart wood on which they feed (Evans 2011). It is therefore reasonable to assume that all 27 species on the list are indigenous to Barrow Island, and current evidence does not suggest any termite introductions have occurred. However, with the development of the LNG facility, strict quarantine and surveillance measures must remain in place on the island, as emphasised by Davidovitch et al. (2009). 
TABLE $1 \quad$ Species of termites recorded from Barrow Island, Western Australia. Sources are Perry (1972); WAM = Barrow Island specimens collected and identified by Perry, in the Western Australian Museum; Atlas of Australian Termites (Watson and Abbey, 1993); Zool. = Zoological Catalogue of Australia, Isoptera (Watson, Miller and Abbey 1998); and specimens from the 2005-09 survey.

\begin{tabular}{|c|c|c|c|c|c|}
\hline & Perry & WAM & Atlas & Zool. & Survey \\
\hline \multicolumn{6}{|l|}{ RHINOTERMITIDAE } \\
\hline Heterotermes ferox (Froggatt, 1898) ${ }^{1}$ & + & & & & + \\
\hline Heterotermes intermedius Hill, 1932 & $+^{2}$ & + & & & + \\
\hline Heterotermes occiduus (Hill, 1927) & & + & & & \\
\hline Schedorhinotermes derosus Hill, 1933) & + & + & & & \\
\hline Schedorhinotermes reticulatus (Froggatt, 1897) & + & + & & & $?^{4}$ \\
\hline \multicolumn{6}{|l|}{ TERMITIDAE, TERMITINAE } \\
\hline Amitermes abruptus Gay, 1968 & + & + & + & & + \\
\hline Amitermes accinctus Gay, 1968 & + & & & & \\
\hline Amitermes darwini (Hill, 1922) & + & + & + & + & \\
\hline Amitermes hartmeyeri (Silvestri, 1909) & + & + & & & + \\
\hline Amitermes innoxius Gay, 1968 & + & + & + & + & \\
\hline Amitermes inops Gay, 1968 & + & + & + & + & \\
\hline Amitermes pandus Gay, 1968 & + & & & & \\
\hline Amitermes pavidus (Hill, 1942) & & + & + & + & \\
\hline Amitermes perarmatus (Silvestri, 1909) & & + & + & + & \\
\hline Amitermes subtilis Gay, 1968 & & & + & + & \\
\hline Amitermes sp. nov. & + & & & & \\
\hline Amitermes sp. nov. & + & & & & \\
\hline Amitermes sp. nov. & + & & & & \\
\hline Amitermes sp. nov. & + & & & & \\
\hline Drepanotermes basidens Watson \& Perry, 1981 & $t^{3}$ & + & + & + & \\
\hline Drepanotermes dibolia Watson \& Perry, 1981 & $+^{3}$ & + & + & + & \\
\hline Drepanotermes diversicolor Watson \& Perry, 1981 & $t^{3}$ & + & + & + & + \\
\hline Drepanotermes rubriceps (Froggatt, 1898) & + & + & + & & \\
\hline Microcerotermes distinctus Silvestri, 1909 & + & + & & & \\
\hline Microcerotermes newmani Hill, 1927 & + & + & & & \\
\hline Microcerotermes serratus (Froggatt, 1898) & & + & + & + & + \\
\hline \multicolumn{6}{|l|}{ NASUTITERMITINAE } \\
\hline Nasutitermes eucalypti (Mjöberg, 1920) & & & & & + \\
\hline Nasutitermes longipennis (Hill, 1915) & & + & + & & + \\
\hline Nasutitermes magnus (Froggatt, 1898) & & & & & + \\
\hline Nasutitermes triodea (Froggatt, 1898) & + & + & + & + & + \\
\hline Nasutitermes sp. nov. & + & & & & \\
\hline Tumulitermes hastilis (Froggatt, 1898) & & & & & + \\
\hline Tumulitermes cf. peracutus (Hill, 1925) & & & & & $?^{4}$ \\
\hline Tumulitermes sp. nov. & + & & & & \\
\hline Tumulitermes sp. nov. & + & & & & \\
\hline Total number of named species & 18 & 20 & 14 & 11 & 11 \\
\hline
\end{tabular}

${ }^{1}$ Heterotermes ferox is apparently a complex of species (Watson, Miller and Abbey 1998), and the H. ferox sens. lat. distribution (Watson and Abbey 1993) includes some H. occiduus.

2 Listed as Heterotermes paradoxus intermedius in Perry (1972).

${ }^{3}$ Listed as Drepanotermes sp. nov. in Perry (1972) but new species described in Watson and Perry (1981).

${ }^{4}$ Species confirmation uncertain because only one soldier collected. 


\section{ACKNOWLEDGEMENTS}

I'm grateful to Jonathan Majer for inviting me to be part of this project. Shae Callan and Nihara Gunawardene kindly sent the specimens and information about Perry's collection in the Western Australian Museum.

\section{REFERENCES}

Abensperg-Traun, M. and Perry, D.H. (1998). Distribution and characteristics of mound-building termites (Isoptera) in Western Australia. Journal of the Royal Society of Western Australia 81: 191-200.

Callan, S.K., Majer, J.D., Edwards, K., and Moro, D. (2011). Documenting the terrestrial invertebrate fauna of Barrow Island, Western Australia. Australian Journal of Entomology 50: 323-343.

Davidovitch, L., Stoklosa, R., Majer, J., Nietrzeba, A., Whittle, P., Mengersen, K. and Ben-Haim, Y. (2009). Info-gap theory and robust design of surveillance for invasive species: The case study of Barrow Island. Journal of Environmental Management 90: 2785-2793.
Evans, T.A. (2011). Invasive termites. In: Bignell, DE, Roisin, Y and Lo, N. (eds) Biology of termites: A modern synthesis, pp. 519-562. Springer: Dordrecht.

Holt J.A. and Lepage, M. (2000). Termites and soil properties. In: Abe, T., Bignell, D. E. and Higashi, M. (eds) Termites: evolution, sociality, symbioses, ecology, pp. 389-407. Kluwer Academic Publishers: Dordrecht.

Lee, K.E. and Wood, T.G. (1971). Physical and chemical effects on soils of some Australian termites, and their pedological significance. Pedobiologia 11: 376-409.

Perry, D.H. (1972). Some notes on the termites (Isoptera) of Barrow Island and a checklist of species. Western Australian Naturalist 12: 52-55.

Watson, J.A.L. and Abbey, H.M. (1993). Atlas of Australian termites. CSIRO Canberra, Australia.

Watson, J.A.L., Miller, L.R. and Abbey, H.M. (1998). Isoptera. Pp. 163-250, in Houston, W.W.K. and Wells, A. (eds). Zoological Catalogue of Australia, vol. 23. Archaeognatha, Zygentoma, Blattodea, Isoptera, Mantodea, Dermaptera, Phasmatodea, Embioptera, Zoraptera. CSIRO Publishing: Melbourne, Australia.

MANUSCRIPT RECEIVED 29 DECEMBER 2012; ACCEPTED 10 APRIL 2013. 